Reviews

\title{
Christoph Irmscher
}

\author{
Paying Mr. Bewick
}

Diana Donald, The Art of Thomas Bewick (with contributions by Paul F. Donald). London: Reaktion Books, 2013. 328 pp. +60 color plates, 150 halftones. $£ 40.00 ; \$ 65.00$.

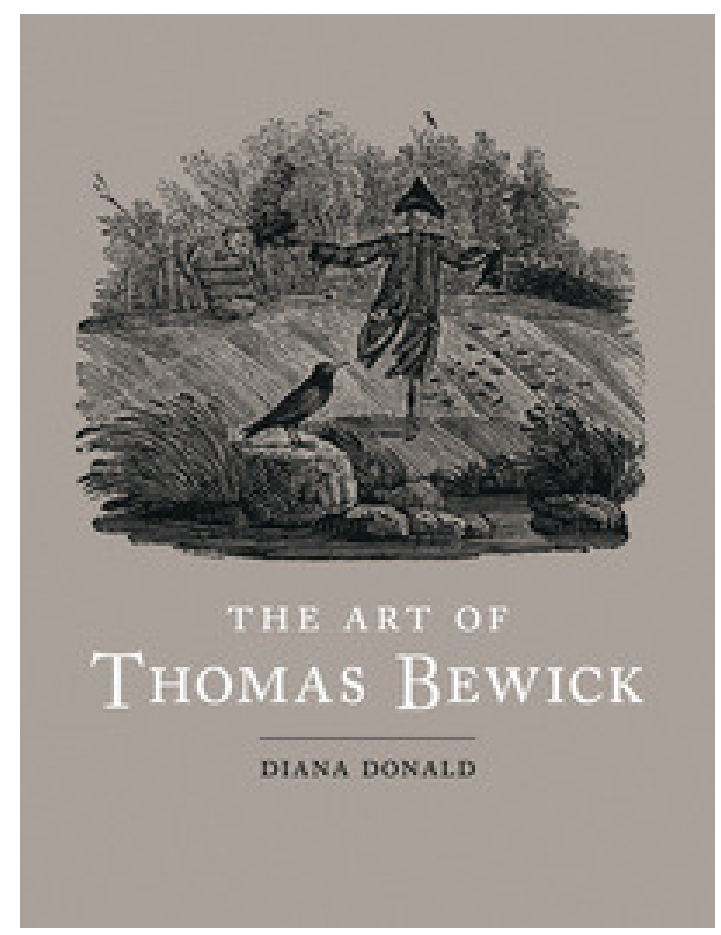

The story goes that, sometime in the 1810s, William Proctor, a poor carpenter's apprentice from the Northumbrian countryside, would walk sixteen miles on weekends just to gaze at a window of a taxidermist's shop in Newcastle. Afterwards, young Proctor would walk home again, as hungry as he had come, dreaming that at least some of the treasures he had seen would one day be his. But what he most specifically coveted was not one of the birds, but a book, in two volumes, the History of British Birds (1797; 1804), engraved and partially written by one Mr. Bewick, known also for his earlier work on quadrupeds (1790). Proctor saved up all the money he could and, on his next visit in town, gathered up his courage, walked into the store, and asked the price of the two volumes. Mr. Bewick, who happened to be present himself, told him that each 
of them was 13s, which happened to be exactly the amount Proctor had saved up. Proctor asked if he could just take one of the books and return for the second volume later, when he had the money. Bewick, in his broad Northumbrian dialect, declined. He did not do business that way, he said. But when he saw the disappointment in the young man's face, he softened, told him to take both volumes and pay for them when he could. Proctor eagerly grabbed the books, but he did not get very far. Three or four miles out of Newcastle, as a friend recalled later, Proctor sat down by the side of the road and began reading. "So absorbed did he become in their contents that he did not cease reading until darkness set in and compelled him to desist" (Robinson xiii). Six weeks later he returned, with the full amount, and Bewick was so pleased that he declined payment: "Well, my lad, I trusted thee when I did not know thee, here's thy money back" (Robinson xiii). William Proctor went on to become the keeper of ornithological collections at the Durham Museum of Natural History. In 1834 and 1837, he traveled to Iceland; apparently, he was the first to suggest that the Great Auk might be extinct.

The story captures nicely why Bewick appealed to so many of his contemporaries, and it reinforces what Diana Donald, in this lavishly illustrated tome, tells us about his art. The immersive experience Bewick's illustrations of birds afforded - precisely the reason that young Proctor got so distracted that he forgot where he was - was the direct result of his innovative handling of the end-grain woodblocks he used. A fairly simple but ingenious trick, the lowering of the wood around the edges of the image, allowed him to create the illusion that his vignettes had no boundaries, and to erase the space between representation and reality. Bewick's innovative use of white line engraving opened up new possibilities for the handling of light and shade, while his decision to place his animals in their appropriate habitats further created the sense that one got a glimpse of nature itself, rather than looking at a specimen in a museum.

Thomas Bewick was a complicated man, full of contradictions. A visionary artist, he was also, in the words of his modern editor, a "jobbing tradesman-engraver" (199); hence his insistence, when Proctor first approached him, that he get fully paid. But apart from being a "Northumberland clod," as John Ruskin somewhat contemptuously called him, his best woodcuts - and this was Ruskin's view, too - rose to the sophistication of Dürer prints (202). And, as the example of Proctor's transformation from carpenter to museum curator shows, Bewick was immensely successful in imparting the importance of scientific literacy to the common people.

Humanimalia: a journal of human/animal interface studies

Volume 7, Number 1 (Fall 2015) 
Yet a friend of ordinary folks he always remained. One of eight siblings, Thomas Bewick knew the nature of hard work. His father's income came from a rented colliery, and he grew up among the people he frequently portrayed in his work - the hardfaced beggars, limping cripples, demobbed soldiers, and rough-and-tumble children featured in his so-called "tail-pieces" or smaller vignettes that he would print at the end of textual descriptions. An ardent abolitionist, pacifist, and supporter of the American Revolution, Bewick nevertheless stopped short of directly challenging the status quo. But his desire for peace and harmony did not prevent him from mocking the empty rhetoric the ruling classes employed to justify war, and he readily condemned the exploitation of both working people and working animals. In one his most memorable tailpieces, a donkey rubs his backside against a memorial stone where the words "Battle ... Splendid Victory ... Immortal" are still legible (119).

For Bewick the boundaries separating humans from animals were porous at best. In her search for influences, Donald points to Jeremy Bentham, who deplored the fact that humans had relegated animals to the status of things, although he remained hesitant to accept that there were close ties between humans and animals. It seems, however, that Bewick in his art did not want to make any such distinctions. In his world, both humans and animals exist in a constant state of degradation. We see horses left outside in driving rain; a dog discovering her drowned puppies, or a sullen performing bear led to the next town, with a joyless circus monkey holding on, for dear life, to its back. While Bewick at least officially never questioned the supremacy of humans, his own work often confronted him with evidence to the contrary. Maybe this is why his version of Fables of Aesop (1818) turned out to be somewhat of a disappointment, in Donald's estimation. Bewick is at his best when he trains his unsparing look on examples of human cruelty to animals, when there's no room for moral uplift or pithy maxims. Fables of Aesop does include one of the most haunting images in Bewick's oeuvre: an old, emaciated, soaking wet horse passively awaiting its own death, as if there were nothing else to do in the world. Bewick was still working on a version of that image when he confronted his own death in 1828. Hardly more than ribs and bones, the animal in that last, unfinished print, a decrepit memento mori, offers a stark contrast with the lush farmland Bewick has chosen as a background. In the distance, dark clouds are gathering. A year before, Bewick had told a friend that he was "becoming like an old Horse," too: "even with whipping \& spurring he cannot with his load climb the hill as he used to do" (175). In a related vignette, he imagined his own coffin being carried out

Christoph Irmscher - Paying Mr. Bewick 
of his childhood home, towards the river where a boat was waiting, the Northumbrian version of Charon ready to carry him across (123).

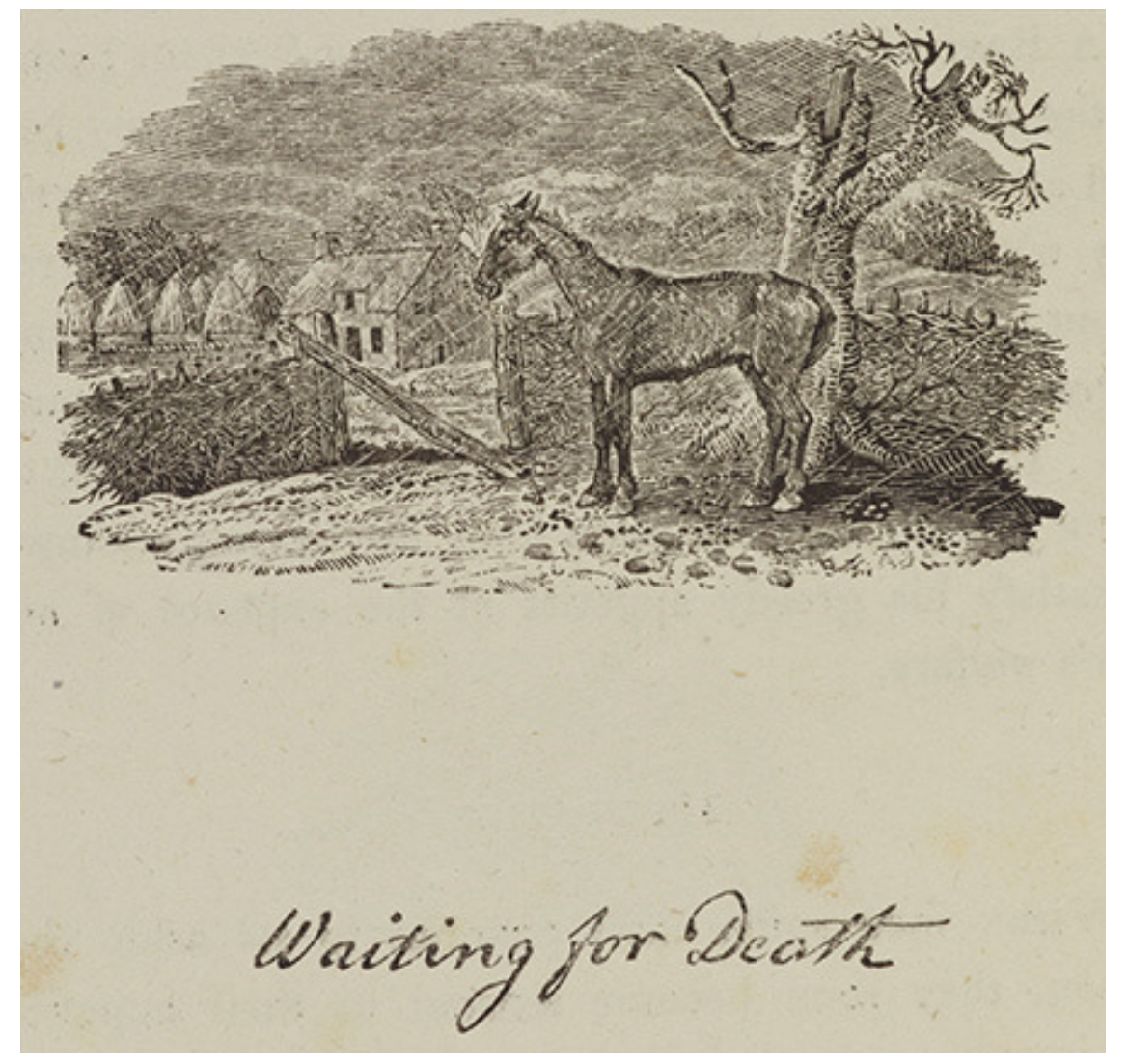

Bewick was not a scientist, a term that was coined only a few years after his death. Donald is candid about what she deems his "insouciant attitude to taxonomy" (59), but she also emphasizes the significant contributions he made to ornithology, the care he put into the accurate representation of a bird's plumage or the selection of species-appropriate habitats. True, he did not feature seasonal or sexual variations, and salient facts about the behavior of his birds he addressed, if at all, in his descriptions or in the tailpieces. But Bewick's representations of birds were based on personal observation wherever possible, and with the descriptions - which in the second volume of Birds were entirely Bewick himself - he tried to account for the nuances of color his woodcuts could not convey. 


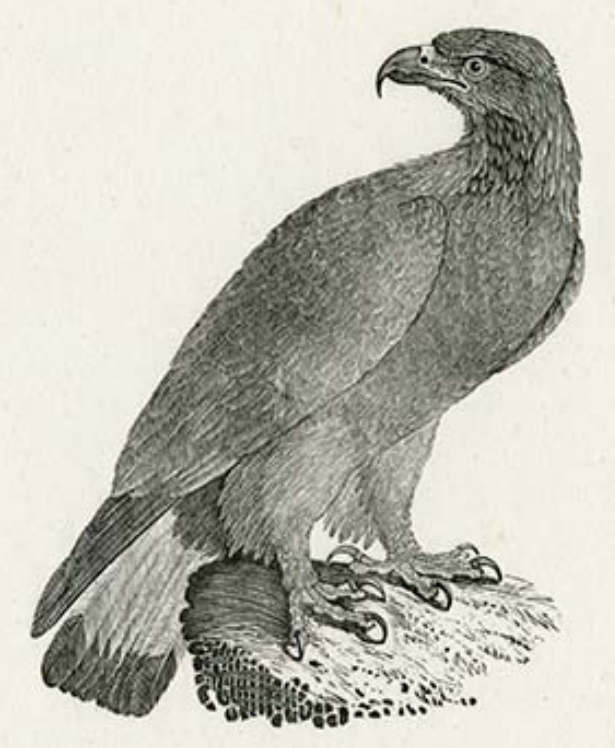

Donald has much to say about the wider cultural context, from Oliver Goldsmith's poetry to the labor activism of William Cobbett, within which to understand Bewick's work, and she provides rich detail about his continuing influence on Ruskin or the Brontës. What became clear to me, though, was the extent to which Bewick's reach extended far beyond his native Britain. For example, John James Audubon and "old Bewick" met in 1827, when the French-American naturalist was spending a week in Newcastle, although by then Audubon was already amply familiar with Bewick's achievements (Audubon, Writings and Drawings 803). In 1821, when he was traveling down the Mississippi, Audubon carried a copy of History of British Birds in his pocket, crowing with delight when the Long-legged Plover (the stilt sandpiper), a small shorebird he saw in New Orleans, corresponded so "nearly" to Bewick's description (Writings and Drawings 99). In fact, "Bewick's birds" inspired not only individual plates in Birds of America (Irmscher 80-81, 90) but shaped the very idea of the later, smallformat edition of the same work, the so-called "Royal Octavo": "Bewick's Size would prove best if the Wood Cuts were equally good," Audubon wrote to his son Victor in 1833 (Audubon decided to use lithographs; Writings and Drawings 823-824). Like Bewick, Audubon limited himself to portraying one species per plate, portraying every feather of their bodies and their habitats with the same fastidiousness that Bewick had 
brought to his task. But what Bewick had relegated to his tailpieces - the awareness that death hovers on the brink of everything humans or animals do - in Audubon's best plates takes center stage. This awareness was what induced Audubon, in one of the earliest plates in Birds of America, to feature not just one but two peregrine falcons on a bare ledge, a male and a female, their beaks bloody from their gruesome breakfast, their eyes turned towards us, the viewers, in full recognition of our own predatory instincts (Birds of America, plate XVI). Neither Bewick nor Audubon, however, was able to realize the inevitable conclusion to be drawn from such insights about our relationship with animals: that our shared mortality should, in an increasingly fragile world, make us not the dispensers and administrators of their dying, but their companions in life.

\section{Works Cited}

Audubon, John James. The Birds of America, from Original Drawings. London: The Author, 1827-1838.

1999.

Writings and Drawings. Ed. Christoph Irmscher. New York: Library of America,

Bewick, Thomas. The Complete Illustrative Work. Ed. Nigel Tattersfield. 3 vols. New Castle, Delaware and London: Oak Knoll Press and The British Library, 2011.

Irmscher, Christoph. "Audubon Goes North." Cultural Circulation: Dialogues between Canada and the American South. Ed. Waldemar Zacharasiewicz and Christoph Irmscher. Vienna: Austrian Academy of Sciences Press, 2013. 77-97.

Robinson, Robert. William Bewick: His Life and Times. Newcastle: Printed for R. Robinson, 1887.

Humanimalia: a journal of human/animal interface studies

Volume 7, Number 1 (Fall 2015) 